\title{
Research-interference: a nomad mode for researching in health
}

\author{
Pesquisa-interferência: um modo nômade de pesquisar em saúde \\ Investigación-interferencia: una forma nómada de hacer estudios en salud
}

Eluana Borges Leitão de Figueiredo'

ORCID: 0000-0002-5462-3268

Eliane Oliveira de Andrade'

ORCID: 0000-0002-0916-9203

Marcela Pimenta Muniz'

ORCID: 0000-0002-8615-7513

Ana Lúcia Abrahão'

ORCID: 0000-0002-0820-4329

'Universidade Federal Fluminense. Niterói-RJ, Brasil.

How to cite this article:

Figueiredo EBL, Andrade EO, Muniz MP, Abrahão AL. Research-interference: a nomad mode for researching in health. Rev Bras Enferm. 2019;72(2):571-6. doi: http://dx.doi.org/10.1590/0034-7167-2018-0553

Corresponding Author:

Eluana Borges Leitão de Figueiredo E-mail: eluanaoft@yahoo.com.br

Submitted: $07-06-2018$

Approved: 09-09-2018

\begin{abstract}
Objective: to discuss search-interference, whose processes are related to the field of health and the social field. Method: theoretical essay used as basis in the philosophy of difference represented by the philosophers Baruch Espinosa and Gilles Deleuze. Results: the present reflection resulted from the meeting of studies from the nursing field that deal with the production of knowledge based on the interference mode. The endeavor of crossing studies produced a theoretical composition presented in three plateaus: interference, a research that welcomes the In-World Experiences; a way of producing researchers; and a nomad mode in health research. Final Consideration: search-interference can be considered as a nomad ethical and political mode for producing research whose consistence plan is provisory, rhizomatic and the result of meetings, forces, intensities and affects produced in the research field.

Descriptors: Methods; Nurse; Philosophy; Knowledge; Nomad.
\end{abstract}

\section{RESUMO}

Objetivo: discutir a pesquisa interferência, cujos processos estão ligados ao campo da saúde e ao campo social. Método: ensaio teórico como base na filosofia da diferença representada pelos filósofos Baruch Espinosa e Gilles Deleuze. Resultados: a presente reflexão resultou do encontro de pesquisas no campo da enfermagem que tratam da produção de conhecimentos a partir do modo interferência. O movimento de cruzar pesquisas produziu uma composição teórica apresentada em três platôs: interferência, uma pesquisa que acolhe as (in) mundices; um modo de produzir pesquisadoras; e um modo nômade na pesquisa em saúde. Considerações Finais: a pesquisa interferência pode ser considerada como modo nômade, ético e político de se produzir pesquisa cujo plano de consistência é provisório, rizomático e fruto dos encontros, das forças, das intensidades e dos afetos produzidos no campo de pesquisa.

Descritores: Métodos; Enfermeiro; Filosofia; Conhecimento; Nômade.

\section{RESUMEN}

Objetivo: discutir la investigación-interferencia, cuyos procesos se vinculan al campo de la salud y al campo social. Método: ensayo teórico en base de la filosofía de la diferencia representada por los filósofos Baruch Spinoza y Gilles Deleuze. Resultados: la presente reflexión resultó del encuentro de investigaciones en el campo de la enfermería sobre la producción de conocimientos desde el modo interferencia. El movimiento de entrecruzar investigaciones produjo una composición teórica presentada desde tres platós: la interferencia, una investigación que acoge las (in)mundicías; un modo de producir investigadores; y una forma nómada en la investigación en salud. Consideraciones Finales: la investigación-interferencia puede considerarse como una forma nómada, ética y política capaz de producir una investigación con un plan de consistencia provisional, rizomático y resultado de los encuentros, las fuerzas, las intensidades y los afectos producidos en el campo de investigación.

Descriptores: Métodos; Enfermeros; Filosofía; Conocimiento; Nómada. 


\section{INTRODUCTION}

This article does not intend to present a new research model, to deny/replace methodologies or to exclude the masculine gender from the scientific language by using the feminine equivalent. On the contrary, the main challenge is to analyze the modes of producing research based on interferences that transit, or rather slip between the modes of researching and communicating differences. Thus, as women, researchers and in view of the eminently feminine historicity of nursing, we use inclusive language as a political stance and as a mode that interferes with the academicscientific tradition of male concordance in writing. The interest in this scientific and communicative slip comes from the different experiences and interferences that students and teachers of the Núcleo de Pesquisa Gestão e Trabalho em Saúde (NUPGES), from the Aurora de Afonso Costa School of Nursing, Universidade Federal Fluminense (UFF), and the line of micropolitical research of the work and health care that the Federal University of Rio de Janeiro (UFRJ) have been developing in their researches.

Thus, we begin from the following question: how to produce health research using mode-search-interference? What are we calling "mode"? When we speak of a mode, we are referring mainly to the philosophers Deleuze and Espinosa and assume other modes of conducting health research. We think a mode is just another way of researching. A way that includes different singularities and emancipatory forms of being constituted as a subject ${ }^{(1)}$.

Regarding the different modes of producing health research, we stress that the present theoretical reflection originated from the confluence of three researches that occurred simultaneously within the scope of the master's and doctorate in health care sciences and that became active forces in the construction of the searchinterference mode. The research developed during the master's focused on basic care, whereas in the one from the doctorate the focus was on mental health and permanent education in health.

The movement of crossing researches required encounters, debates, studies, exchanges, knowledge, field and life experiences which, when entering a knowledge production movement, resulted in a plural mode of using interference and, at the same time, a singular mode to do research in the research field. The intertwining of research that resulted in the reflections of this study were caused by an intense movement of composition with the experiences of each one of us - nurses and researchers - that, in launching ourselves in the craft field of exploring experiences, we move from the place of the subject of information, of opinion, of work, of research, of knowledge, of doing, of power and of will, and we move on to a nomad, wandering and errant movement to transit between methodologies in how they approach and then to compose ourselves, to allow ourselves to be like a territory in transit, open, a passageway of what happened in the research field.

Thus, from the use of the nomad mode of researching in health, it was possible to make difference, multiplicity and singularity thinkable, in accordance with the philosophy of difference proposed by Gilles Deleuze and Félix Guattari. Thus it was from another form of grasping knowledge - the perspective of difference - that the effects and results of this reflection were generated and reassembled in the form of plateaus, as a set of broken rings that can penetrate each other. That is: interference, a research that welcomes In-World
Experiences; interference, a mode of producing researchers; and interference, a nomad mode in health research. The objective of this article is to discuss interference research, whose processes are related to the field of health and the social field.

\section{INTERFERENCE, A RESEARCH THAT WELCOMES IN- WORLD EXPERIENCES}

In the history of health sciences, the myth of objectivity constituted the epistemological architecture of knowing, knowledge and doing research based on the method as a possibility to make research safe, impersonal, neutral, valid and reliable. That is, research that allows a certain domain of the object of study ${ }^{(2)}$. The matter-discussion of this study is precisely that of domain. How can we think of building a mode of research that escapes the dominant totalization in the production of knowledge? Is it possible to present to researchers, teachers and students other possibilities of intensive productions, that include the other in all their diversity and difference? How to produce modes of researching in health that are constructed based on the encounter between researcher and object in a nomadological perspective?

Amador et al. ${ }^{(3)}$ call attention to strategies of knowledge production that adopt different rules, since not always the method will be able to account for the variations, forces and events that are produced in a given field of research.

In this sense, it can be seen that the ideal models of research, as sustained by the positivist tradition, have suffered a cut in their historical continuity, since several methodological trends (intervention research, participatory research and action research) have caused important epistemological shifts. They invent certain ways or modes of grasping the classical perspectives of knowledge production, and make participation in the field an investigative political $\mathrm{act}^{(3)}$. Regarding the specific field of nursing, convergent care research (CCR), which was elaborated by the nurses Dr. Mercedes Trentini and Dr. Lygia Paim, has been an alternative and important mode of research ${ }^{(4)}$.

Among all the methodological tendencies mentioned, we emphasize that intervention research is the closest to interference mode, since from it are woven some epistemological alliances of deconstruction, the questioning of traditional research approaches and radical intervention in the field of micropolitics. It does this by opposing the separation between subject and object and through the non-existence of scientific neutrality. The only difference is that interference triggers the need of using any tools in the field (not before it), since it puts a state of body that is alert to what the field asks for as a necessity of the researcher and not the other way around. Thus, in order to advance the understanding of what would be a mode-research-interference in the field of health, we engaged in the challenge of suspending the semiotic codes of methods in order to think interference from the point of view of nomad modes of research that unfolds upon itself, referring to the concept of pororoca of Abrahão(5). According to the author, this meeting of waters has the ability to produce a fold, a return, an effect on itself. That is, the pororoca effect in the research is a producer event in the researcher's own action.

Let us take the studies that address the conditions on the healthdisease process as an example of interference mode in the research. 
The argument and assertion of there being a curativist, hospitalcentered, biomedical and systematized logic is recurrent, with this logic being valued both in scientific practice and production. They are productions with predominance of methods and previously planned interventions, as well as controlled exposure by the researchers. However, it must be considered that such research, in order to be considered scientific, must let escape that which disturbs it, something marginal, producing a hygienist effect, since the results try to free both writing and In-World Experiences themselves found in the trajectory of these studies ${ }^{(5)}$. The term $\mathbf{I n}$-World Experiences was borrowed from Abrahão et al. ${ }^{(5)}$ when they refer to the researcher's process affecting and mixing with the object in the research process.

Let's look at research on diabetes management, for example. Often such studies address different perspectives of diabetes, but they cannot dismiss the disease as anything other than the main focus, that is, there is difficulty accommodating deviations from the pattern and understanding it as a possible way of life. Perhaps this is due to a scientific tendency to normalize and standardize the body, putting in the parenthesis, in the place of exception, the disease. As an example of standards we have: normality parameter of glycemic indexes, standardization of signs and symptoms, definition of new diagnoses, delimitation of chronicity complications, establishment of new medications, among others. Many of these enunciates affirm a pattern in the logic of illness, without considering life as a variation, as a singularity or a difference, and turn the disease an out-of-body experience in order to better observe, analyze and measure, thus displacing it from the production of existence of the subject, in such a way that illness is part of living and is not an exception to anyone's life.

Here, we call variation, as in the example above, the singularity of the individual with diabetes, who, despite having high glycemic levels, can establish a relationship with the disease itself outside acceptable scientific standards and that, yes, can live a powerful life despite the inadequacy of scientifically established parameters. But in biomedical science, if this In-World Experience ${ }^{(5)}$ is accepted, research loses its truth status and scientificity, that is, it produces no more evidence or truths that are considered viable by science. These are called biases and confusions, they are precision errors, validity errors, selection and information biases; aspects that limit the validity of the study.

How would the researchers in interference mode work on their research considering the same problem and object of research? Well, the researcher, to enter the field, would produce for herself a slightly prepared body, which does not mean that she goes into the field with orders ready and previously thought methods. It goes with a world of possibilities for nomadic slips between methods, which will only be triggered and activated by/in the field. In the case we are working on, the researcher would take a toolbox with all the scientific knowledge and scientific standards of diabetes, take their remarks and previous experiences with the disease, as well as some hard technologies such as pen, recorder, notebook, glycemic apparatus, glycemic test tapes, and everything one might consider as having a potential use as the field and the body ask for it in action. But there is something that the researcher, in the mode of interference, could not fail to consider in the research: the different relationships existing in the field - the user's relation with diabetes, the researcher's with the user, diabetes with the type of research, the research with the field, and many other possible combinations. In-World Experiences ${ }^{(5)}$ are not only accepted in the research process, but also necessary for the displacement of truths produced in the field, since the researcher produces based on In-World Experiencing ${ }^{(5)}$ and singularities.

In this way, interference is an ethical, aesthetic and political mode of conducting research, whose plan of transient and open consistency is subordinated to relations, forces, intensities, affections and In-World Experiences ${ }^{(5)}$. A place, a space of fruition in research, is created between the movement of researching and experimenting, observing and In-World Experiencing the research object.

\section{INTERFERENCE, A MODE TO PRODUCE RESEARCHERS}

In order to understand interference as the researcher's mode of production, we continue with the schizoanalysis, which gives us the possibility of using concepts as tools in the field and in writing, since it privileges concepts and the relations they establish in a given context, to the detriment of the individual or isolated terms. It is curious that we are speaking in this article about methodological approaches to research while making use of philosophical concepts. But it is not inappropriate, since the philosophy of Deleuze and Espinosa helps us rethink the regime of production of truths in health research. When we consider the field of health research as a field of forces in this discussion, a new body is necessary for the researcher who wishes to venture into this mode of research. The Cartesian body is no longer fit, for it is a body divided between thought and existence, a body that has "the duty of", "the function of", "the purpose of". The body that summons us is the body in its capacity to affect and be affected by others ${ }^{(6)}$. The anatomical eye endowed with the purpose of seeing, observing, capturing the structure, photographing the moment by framing reality is also not enough, it is necessary to trigger other perception tools that capture forces and events.

So, with what body do we start for this research? How can the body respond to intensive and extensive field demands? What kind of body is it that sustains the vibrations and interferences of the other within itself? We dare say that it is necessary to invent/create/ produce a body-researcher for interference modes! The philosophy of Espinosa ${ }^{(6)}$ and Deleuze ${ }^{(1)}$ has helped us think the body in a more complex manner than the anatomical one. For them, the body is of any nature, material or immaterial, as, for example, a book, music, place, collective, struggle, friend, work, conversation, among many other infinite bodies liable to cause and suffer interferences.

Therefore, a body is defined by the relationships that it can and is capable of being and doing. And what do we know about the power of the body when it is in the research field? Espinosa gives us clues that body and thought are on the same plane. And much of what we know about the body came from the thought of René Descartes. His philosophy divided body and thought, and to this day we have gathered the effects of this division. We learn through Cartesian thinking that the researcher's body should not be affected or combine with the research object. We learn that this body must be neutral, indifferent, objective.

In interference we adopt a body that affects and is affected. And with each interference, research changes, being permanently in this state of affectation, where research is always an unfinished 
process. By unfinished, this does not mean scholarly sloppiness or incompleteness, but rather a constant provisionality. It is precisely in the construction of openings that multiplicities and interferences can be supported and accepted as a part of knowledge capable of provoking changes in the mode of producing research in the field of health. One cannot mistake the term openness with an open, unruly and irresponsible way to construct research. On the contrary, the process of constructing openings is highly rigorous, as it is based on the ethics of life. For Andrade ${ }^{(7)}$, it is necessary to invest on an ethics that requires the subjects to reinvent the modes to relate with themselves, with the others and with their own truths.

Here, an unsuspecting reader could confuse the term openings with mere yes or yes to everything. The violence experienced in the encounter between a body and another makes the researcher demand construction, during the action, of methodological tools with plastic capacity to attend to what the meeting brings up. This body, necessary to research, produces and receives interference the whole time. A fact different from the principle of objectification sustained in classical science, in which the subject conceives himself as being outside nature, disconnected from the object he constructs and studies ${ }^{(8)}$. Rigor is what will make interference research visible. This means that the researcher must be lightly prepared to devise, during the act, modes of being in the field that are constituted by multiplicities to the same extent required by the context in which they find themselves. Interference occurs in the event, in the act, in the encounter.

We use Spinoza's philosophy in this context, because it allows to observe that the relation between bodies is given independently of their will, transposing this thought to research. Therefore, the researcher is the owner of a body that is always affected and does not cease to affect. We call this a body-researcher. Considering this fact, the researcher invariably interferes in the research, since the meetings do not stop happening. The researchers, by themselves, change the field, the research and the participants through the meetings they make. What does this have to do with interference research? Everything! Based on the understanding that observation alone produces interferences, the researcher can no longer avoid interfering with their body and from the meetings they conduct in the research field. In this way, as Moebus(9) states, interference is part of being researcher and not a distortion or vice to be purged. However, this mode of accepting different possibilities of producing research has been reckless for many researchers who refer to research that uses such approaches as less scientific and susceptible to interference by researchers ${ }^{(10)}$.

The concept of the neutral, impartial researcher, unaffected by the field and relationships, no longer holds. In interference research, the researcher's body is marked by affections and compositions, and therefore produces a certain affirmation of production of knowledge that makes it active, inventive, creative. The body, the field, the writing and knowledge are produced according to how they are situated in the power relations in which they are able to interfere and undergo interferences. It occurs, in the researcher, the activation of a will to interfere that is built on a plane of experimentation. The researcher then becomes constructive and provocative due to the interferences produced that make them vibrate.

In this mode-research-interference, the body-researcher does not give place to knowledge as truth, but it allows for the construction of other kinds of knowledge by bringing forth a provisional truth, an expression, a mode, the co-creation of worlds with the object. Thus, the proposal of producing new territories in the construction of health research takes place as a movement that produces waves, displacements, a movement whose ability is to invoke the unspoken. All of this makes one think that there are several truths. And that truths are human productions, made by anyone. However, when we frame the discourse of scientific truth, we run the risk of despising what we call minor knowledge, the knowledge of the folk, and thus trigger an accustomed mode that reproduces absolute truths due to considering them more comfortable and secure. But by assuming interference as a mode of being in the field of research, researchers then compose with any body, with any knowledge, and of any nature, different truths that make sense in the field of health care.

\section{INTERFERENCE, A NOMAD MODE IN HEALTH RESEARCH}

When we assume interference research as a way of constructing openings, we are corroborating with what Deleuze and Guattari $i^{(1)}$ called nomad, which takes this nomadological trait as a strategy of sliding by the dominant modes. In nomad mode, there are only lines, processes, intensities, variations and a production of worlds in agreement with the subjects and objects that constitute them. Through these propositions we ask: how to practice a nomad mode of researching in health? To better understand the nomad mode, let's return to the example provided in the previous category focused on diabetes research. When the interference mode is used in research, we do not start from the existence of dichotomous sides, that is, either biomedical science or mode-interference. We do not regard them as opposites. They are only worlds and versions that are dependent on one another and subjected to coexistence. In interference mode, what determines the methodological instrument will be the field, body and relationships that the researcher establishes with the disease, with the subject, processes and forces that will be at play in the plurality of the existence of life with diabetes. It is precisely in the possibility to transit between modes that resides the nomad trait.

To clarify what would be a mode-interference and a nomad trait of research that produces a shifting of scientific truths, let's suppose the following scenario, still regarding diabetes. Scenario 1 : the researcher leaves for a research with prior instruments, with questions ready and with well-defined objectives and meets a certain diabetic participant. We consider this to be a solid, closed space, considering the relation between subject and object in a given research field. A relationship with the objective of collecting data and collecting what the participant has to say about the research object delimited by the researcher. The positions of subject and object are clearly defined: the researcher in the position of collecting data, often with their tape recorder or interview script; the researcher in the position to offer information that will be consumed a posteriori by the researcher. The positions are set: separate researcher and object. Without the researcher's position being transcendent to the object there would be no research. What if at a given moment there is an unforeseen event that completely changes the course of the interview? A sudden hypoglycaemia that causes the body of the fainting subject to fall to the ground? There must be an effort to bring back order, unity, and balance. 
In this scenario, it is not that there is no interference, on the contrary, as we have already said, a body always affects and is affected. Here the problem lies in the fact that this researcher is already accustomed to not providing transit or passage to this process of experiencing the In-World Experiences ${ }^{(5)}$ of the field. It collects the effects of interference only as marginal events, which are not explicit in writing, in the analysis of the research, because, as a rule, this out-text or out-research is seen as nonknowledge that should be excluded from the research. In the hygienic process of textual manners, a priori, in the customary body, what the researcher can consider as clean has already been established. This would be understood as truth data, which are limits already previously placed on this type of construction.

Ultimately, the researcher is traditionally already going to the field knowing what fits and what does not fit into their research, letting escape minor knowledge, which, as a rule, is considered as disqualified by the regime of truth from Cartesian science. It is this minor knowledge captured by the Cartesian truth that mode-interference does not want to leak or clear from research. On the contrary, only through the construction of a state of inclusive possibility that one is able to research, making no sense using such a dichotomy as good/evil, clean/dirty.

Let's look at Scenario 2: the researcher leaves for the research field slightly prepared, because they uses their methodological arsenal with porosity to incorporate the demands of what lies ahead. They know, a priori, that they are in an open, fluid field, which collects mainly that which is unexpected, without control. The researcher is attentive. They create and activate, in the field, their transient research tools, which may be a journal, a tape recorder, a skin, a radar, a memory. It leads to questions; however, the researcher can hear the silence of non-answers and the annoyance posed by the creation of the body-researcher that implies in: feeling burning, hurting, seeing worlds being broken, absolute truths crumbling and dismantling their research/life hypotheses. Suddenly, the researcher sees the body of the diabetic participant fall over, faint in hypoglycemia... What happens to the research? The researcher in interference mode welcomes the tragic, giving way to the creation of other worlds, since they do not see the trait of failure or defeat in the catastrophic, but understand that it is part of the process of producing themselves as researchers, and that this mode has as production strategy the experimentation that slides between the spaces, interfering and being actively interfered in the field. The researcher welcomes that fact and incorporates it into the research. Let us say that, at the moment of the event, a third element enters the scene, welcoming in a profound, affectionate and careful way the one who is faint? The care given to the subject moves the researcher, causes them to think of other ways of dealing with situations like these. The researcher is not so focused on the ideal parameters of blood glucose, the signs and symptoms presented by the user, but is attentive to what happens in the environment, including putting their implication on seeing the scene happen. Thus, the demarcations between subject and object dissolve. It is no longer a question of research - what is at stake are the relations with the life of the diabetic, life that does not stop happening and that does not stay fixed to the normative and scientific look of the researcher. Only the In-World Experiences ${ }^{(5)}$, the diversified encounters and knowledge that are activated from the different bodies remain. Thus, knowledge-research and other kinds of knowledge are produced in coexistence, if composing, creating new knowledge, new practices, new knowledge. The nomadic mode of interference research creates in the field and in life infinite possibilities of receiving multiplicities.

However, experience with surveys from the perspective of interference mode shows that there is no static field to be explored. The field and the researcher body are always provisional, under the process of being, they are passages that give way to the transit of intensive interferences of the researcher. Researcher, research and researched are mixed with the same movement of interference. Thus, interference occurs through the very presence of the body-researcher when it becomes capable of capturing the current production. It is not a matter of exploring a field, but of co-creating worlds in which, in the existential territory, one is produced with/in the other, in a movement of creation and deconstruction of oneself.

\section{FINAL CONSIDERATIONS}

In this reflection we start from the assumption that there are several ways of producing health research and that, among them, there are those of greater domination. For such we intend, therefore, to problematize modes that allow access to different ways of researching health in nursing and other professional categories, offering them possibilities of slippage among the methods through the reception of accidents, deviants, schizos, smaller sets of knowledge production. Thus, this study presented a theoretical arsenal to think of research as a nomad production, as an escape line towards a practice that, in its dynamics of affirmation and resistance, functions as a welcoming research device for all kinds of knowledge that the field has to offer.

Thus, in the practice of any health researcher, interference research can be a seismic movement in the mode of doing research, which can reverberate in health routine by proliferating worlds, performing realities, promoting care and powerful encounters between researcher and research, since in this mode the researcher is no longer neutral, subjects are no longer passive and the field is no longer static. Everything starts moving, in composition.

\section{REFERENCES}

1. Deleuze G, Guattari F. Mil platôs: capitalismo e esquizofrenia. Rio de Janeiro: Editora 34; 1996.

2. Romagnoli RC. [Cartography and relationship between research and life]. Psicol Soc [Internet]. 2009 [cited 14 Jun 2017];21(2):166-73. Available from: http://www.scielo.br/pdf/psoc/v21n2/v21n2a03.pdf Portuguese.

3. Amador FS, Lazzarotto GDR, Santos NIS. [Search-act, search-intervene, search-interfere]. Rev Polis e Psique [Internet]. 2015 [cited 4 Jun 
2017];5(2):228-48. Available from: https://seer.ufrgs.br/index.php/PolisePsique/article/view/58180 Portuguese.

4. Cortes LF, Padoin SMM, Berbel NAN. Problematization methodology and convergent healthcare research: praxis proposal in research. Rev Bras Enferm [Internet]. 2018[cited 2018 Jul 1];71(2):440-5. Available from: http://www.scielo.br/pdf/reben/v71n2/0034-7167reben-71-02-0440.pdf

5. Abrahão AL. O pesquisador IN-MUNDO e o processo de produção de outras formas de investigação em saúde. In: Gomes MPC, Merhy EE (Orgs.). Pesquisadores IN-MUNDO: um estudo da produção do acesso e barreira em saúde mental. Porto Alegre: Rede UNIDA; 2014. p. $155-70$.

6. Spinoza B. Ética. Belo Horizonte: Autêntica; 2015.

7. Andrade EO, Givigi LRP, Abrahão AL. [The ethics of self-care as a way of creating possibles for work in Health]. Interface (Botucatu) [Internet]. 2018[cited 2018 Jul 1];22(64):67-76. Available from: http://www.scielo.br/pdf/icse/v22n64/1807-5762-icse-1807-576220160643.pdf Portuguese.

8. Neves CEAB. Modos de interferir no contemporâneo: um olhar micropolítico. Arqu Bras Psicol [Internet]. 2004[cited 2018 Jul 1];56(1):02-20. Available in: http://pepsic.bvsalud.org/scielo.php?script=sci_arttext\&pid=S1809-52672004000100002\&lng=pt

9. Moebus RLN. Pesquisa interferência desde Heisenberg. Diversitates. 2015;7(1):54-61.

10. Silva JC, Morais ER, Figueiredo MLF, Tyrrell MAR. [Action research: concepts and applicability in Nursing studies]. Rev Bras Enferm [Internet]. 2011 [cited 2018 Jul 1];64(3):592-5. Available from: https://bit.ly/2TPm9SU Portuguese. 